\section{Infection with Yersinia enterocolitica in patients with iron overload}

Yersinia enterocolitica commonly causes fever and mild gastroenteritis' but occasionally causes severe illness, particularly in patients with iron overload in whom its virulence is enhanced. ${ }^{2}$ Desferrioxamine used therapeutically may potentiate the growth of yersinia, which uses desferrioxamine as a siderophore to chelate iron. ${ }^{3}$ We describe three patients with transfusional haemosiderosis and infection with $Y$ enterocolitica.

\section{Case reports}

CASE 1

A 25 year old white man with congenital sideroblastic anaemia, which had been diagnosed in 1965 and who had subsequently received regular blood transfusions (450 units) and subcutaneous desferrioxamine (serum ferritin $2460 \mu \mathrm{g} / \mathrm{l}$ ), was admitted with symptoms of anaemia, three days of fever $\left(39.5^{\circ} \mathrm{C}\right)$, slight diarrhoea, which he initially denied, but no abdominal pain.

He had hepatomegaly $(10 \mathrm{~cm})$ and slight abdominal tenderness. His haemoglobin concentration was $53 \mathrm{~g} / \mathrm{l}$ with normal white cells. The day after admission he started to receive a blood transfusion of three units with $6 \mathrm{~g}$ of desferrioxamine. Within eight hours he had severe diarrhoea, after 12 hours severe dyspnoea due to a persistent metabolic acidosis (bicarbonate $13 \mathrm{mmol}(\mathrm{mEq}) / \mathrm{l})$, and by 40 hours he had died. Intravenous penicillin, gentamicin, metronidazole, and rehydration were given to no avail.

Necropsy showed an ulcer in the terminal ileum, multiple tiny colonic ulcers, and grossly enlarged purulent mesenteric lymph nodes. Stools and blood culture later grew $Y$ enterocolitica.

CASE 2

A 19 year old Greek Cypriot woman with $\beta$ thalassaemia diagnosed at 3 years and splenectomy at 8 years had received regular blood transfusions ( 200 units) but refused subcutaneous desferrioxamine. Her serum ferritin concentration was $1720 \mu \mathrm{g} / \mathrm{l}$ and white cell ascorbic acid $7 \mu \mathrm{g} / 10^{8}$ cells. ${ }^{4}$ She was admitted with 24 hours of fever $\left(38^{\circ} \mathrm{C}\right)$, malaise, one loose stool, and tenderness in the right iliac fossa. Her haemoglobin concentration was $78 \mathrm{~g} / \mathrm{l}$ and white cell count $27 \cdot 8 \times 10^{9} / 1$ with a neutrophilia of $92 \%$. Blood culture yielded negative results. Penicillin was given. The next day she discharged herself and returned in three days to receive three units of blood with $6 \mathrm{~g}$ of desferrioxamine. Two days after transfusion she was readmitted with fever, severe diarrhoea, and pain in the right iliac fossa, where a mass had developed. Yersinia infection was diagnosed.

Intravenous mezlocillin and netilmicin were given, and eight hours later in a dramatic recovery her temperature settled. Desferrioxamine was withheld. A few days later the diarrhoea and mass resolved. $Y$ enterocolitica grew profusely from her stool. The $Y$ enterocolitica titre in her blood taken at discharge was $1 / 20$ and five months later $1 / 320$.

CASE 3

A 22 year old Greek man with $\beta$ thalassaemia major received regular blood transfusions in Athens and subcutaneous desferrioxamine (his serum ferritin concentration was $1700 \mu \mathrm{g} / \mathrm{l})$. He was referred to London because of recurring abscess formation in the right inguinal region for five months. Pus had grown $Y$ enterocolitica, and he had received various antibiotics. Desferrioxamine treatment had been withdrawn. The abscess in the inguinal region, which was discharging pus, and several smaller retroperitoneal abscesses, with a sinus extending to the psoas muscle, were surgically drained and debrided. Tetracycline, clindamycin and penicillin were given together with local irrigation with hydrogen peroxide. He made a good recovery.

Yersinia was not cultured, possibly because of previous antibiotic treatment. The patient's yersinia titre was positive at $1 / 1280$.

\section{Comment}

We have described three patients with iron overload, two of whom were treated with subcutaneous desferrioxamine, who developed infection with yersinia and right iliac fossa disease. Two patients (cases 1 and 2) with mild intercurrent infections received routine transfusions with intravenous desferrioxamine $6 \mathrm{~g}$ and then became severely ill. One of these patients (case 1), who had previously received daily subcutaneous desferrioxamine, died 40 hours after transfusion, the other (case 2), who had refused regular desferrioxamine treatment but whose iron stores were lower survived. The third patient (case 3 ) developed chronic multiple abscesses and survived. Desferrioxamine treatment had been withdrawn.

Desferrioxamine may potentiate yersinia infection in patients with iron overload and has been shown to cause systemic yersinia infections in healthy children who received desferrioxamine after iron overdosage. ${ }^{5}$ Our observa- tions, although anecdotal, suggest that desferrioxamine treatment should be temporarily withheld in febrile patients with iron overload, especially those with gastrointestinal symptoms, and appropriate antibiotics given at once.

1 Marks MI, Pai CH, Lafleur L, Lackman L, Hammerberg O. Yersinia enterocolitica gastroenteritis A prospective study of clinical, bacteriology and epidemiologic features. I Paediatr 1980;96:2631 .

2 Robins Browne RN, Robson AR, Koornkof $\mathrm{HJ}$. Generalised infection with Yersinia enterocolitica and the role of iron. Contrib Microbiol Immunol 1979;5:277-82.

3 Robins Browne RM, Prpic JK. Desferrioxamine and systemic yersiniosis. Lancet 1983;ii: 1372.

4 Chapman RWA, Hussain MAM, Gorman A. Effect of ascorbic acid deficiency on serum ferritin concentration in patients with beta thalassaemia major and iron overload. 7 Clin Pathol 1982;35:487-91.

5 Melby K, Slurdahl S, Gutteberg TJ, Nordbo SA. Septicaemia due to Yersinia enterocolitica after oral overdose of iron. BrMed f 1982;285:467-8.

(Accepted 25 September 1985)

Departments of Paediatrics and Haematology, Royal Free Hospital, Hampstead NW3 2QG

$\mathrm{H}$ Y CHIU, MRCP, lecturer in paediatrics

D M FLYNN, MD, FRCP, consultant paediatrician

A V HOFFBRAND, FRCP, FRCPATH, professor of haematology

Thalassaemia Unit, Hellenic Red Cross, Athens

D POLITIS, MD, director

Correspondence to: Dr Chiu.

\section{Acute renal failure associated with acute pyelonephritis and consumption of non-steroidal anti-inflammatory drugs}

We report four cases in which urinary infection precipitated acute renal impairment in patients taking non-steroidal anti-inflammatory drugs.

\section{Case reports}

Case 1-A 27 year old woman with seronegative arthritis was admitted with a five day history of right loin pain and fever. For three years she had been taking azapropazone $2.4 \mathrm{~g}$ daily. She had had a urinary tract infection two years previously. Renal function then had been normal, although intravenous urography had shown pelvicaliceal clubbing. On examination she was feverish with tenderness in the right loin. Plasma creatinine concentration on admission was 199 $\mu \mathrm{mol} / \mathrm{l}(2 \cdot 3 \mathrm{mg} / 100 \mathrm{ml})$ (calculated creatinine clearance $44 \mathrm{ml} / \mathrm{min}$ ). Intravenous urography and ultrasound scanning showed an enlarged right kidney with poor excretion. Urine and blood cultures were sterile, but treatment with antibiotics had been started before admission. Intravenous co-trimoxazole improved her condition, and within three days renal function had returned to normal. Although azapropazone was stopped, she developed a further episode of pyelonephritis four weeks later, during which renal function remained normal.

Case 2-A previously fit 61 year old woman presented with a five day history of rigors, vomiting, and right loin pain. Ten days previously she had begun taking ketoprofen $400 \mathrm{mg}$ daily for pain in her right knee. On admission she was feverish and dehydrated with tenderness in the right loin. Plasma creatinine concentration was $244 \mu \mathrm{mol} / 1(2.8 \mathrm{mg} / 100 \mathrm{ml})$ and Escherichia coli was cultured from a midstream specimen of urine. Despite treatment with intravenous fluids and ampicillin plasma creatinine concentration rose to $819 \mu \mathrm{mol} / \mathrm{l}(9 \cdot 3 \mathrm{mg} / 100 \mathrm{ml})$ four days later, and peritoneal dialysis was therefore begun. Within five days her renal function had improved and dialysis was stopped. Intravenous urography during convalescence showed a poorly excreting right kidney. Four months after admission plasma creatinine concentration was $126 \mu \mathrm{mol} / 1(1.4 \mathrm{mg} / 100 \mathrm{ml})$.

Case 3-A 64 year old woman with a long history of rheumatoid arthritis presented with a three week history of nausea, vomiting, dysuria, rigors, and confusion. After a year's treatment with penicillamine she had taken naproxen $750 \mathrm{mg}$ daily for two years. Six months before admission plasma creatinine concentration had been $164 \mu \mathrm{mol} / \mathrm{l}(1.9 \mathrm{mg} / 100 \mathrm{ml})$. Plasma creatinine concentration on admission was $1285 \mu \mathrm{mol} / \mathrm{l}(14.5 \mathrm{mg} / 100 \mathrm{ml})$, and $E$ coli was grown from the urine. She was treated with peritoneal dialysis and intravenous ampicillin, ceftazidime, and flucloxacillin. Dialysis was stopped after four days, and within three weeks plasma creatinine concentration was $377 \mu \mathrm{mol} / 1(4 \cdot 3$ $\mathrm{mg} / 100 \mathrm{ml}$ ). Ultrasonography showed bilateral small kidneys, and renal biopsy showed changes of acute on chronic pyelonephritis.

Case 4-A 71 year old woman was admitted with a fractured neck of femur. A left nephrectomy had been performed for tuberculosis 20 years previously, but plasma creatinine concentration one month before admission had been 120 $\mu \mathrm{mol} / \mathrm{l}(1.4 \mathrm{mg} / 100 \mathrm{ml})$. Six days before admission she had started taking ibuprofen $1.2 \mathrm{~g}$ daily for backache. On admission she was dehydrated and confused. Plasma creatinine concentration was $177 \mu \mathrm{mol} / \mathrm{l}(2.0 \mathrm{mg} / 100 \mathrm{ml})$, and $E$ coli was grown from the urine. Despite rehydration and administration of 